I. M. Matsyuk ${ }^{1}$, Cand. Sc. (Tech.), Assoc. Prof., orcid.org/0000-0002-0861-0933,

E. M. Shlyahov ${ }^{1}$, orcid.org/0000-0001-5983-9853, O. I. Yehurnov², Cand. Sc. (Tech.)
1 - Dnipro University of Technology, Dnipro, Ukraine, email: shlyahove@nmu.org.ua

2 - Ana-Tems Ltd, Dnipro, Ukraine, e-mail: yegurnov@yahoo.com

\title{
SUBSTANTIATION OF RATIONAL DRIVE PARAMETERS FOR RELIABLE OPERATION OF HEAVY-LOADED MECHANISMS
}

Purpose. To evaluate the influence of driven crank parameters on the location of different sets of a mechanism with the fourthclass structural group.

Methodology. A theoretical study on the influence of the input crank parameters on the positioning of different sets of the mechanism of a double-jaw crushing machine using the Mathcad software was carried out.

Findings. It is shown that:

- the center of rotation and the length of the crank in the fourth-class mechanism should be positioned in a certain area;

- the choice of specific positioning of the crank can eliminate the dangerous proximity of two adjacent sets of the mechanisms of the fourth-class structural group.

Originality. An algorithm of defining a zone of positioning the rotational center and length of a crank is determined for plain mechanisms of the fourth-class structural group. It has also been found that probability of spontaneous transition from one assembly to another closely-spaced assembly in heavy-loaded mechanisms can be reduced significantly by choosing the appropriate rotational center of a crank.

Practical value. An algorithm of actions is proposed, which makes it possible to choose an assembly which ensures its good functioning during the synthesis of a plain heavy loaded mechanism of the fourth class.

Keywords: mechanism, synthesis, structural group, assembly, crank, jaw crusher, Mathcad program

Introduction. The theory of mechanisms and machines, as a science, was formed at the beginning of the $19^{\text {th }}$ century. The main object of the research at that time was the simplest plain mechanism consisting of four links, later referred by L. V. Assur to the second class. Over the last two centuries, the results of the study of this mechanism have been published in dozens of articles and books. It seems that this mechanism, as we say, has been the subject of thorough studies, but the work continues to appear up to date.

Literature review. For example, in [1], the synthesis issues of a four-bar leverage are discussed and the method based on Chebyshev's theorem and Freudenstein's equation is described.

In [2], the synthesis of a four-bar leverage is also considered on the basis of the Chebyshev-Freudenstein method at six given points of the position function of the mechanism.

In [3], a classification of the four-bar leverages is proposed, based on their geometric and kinematic characteristics. The classification simplifies computer modeling of analysis and synthesis mechanisms.

In [4], in order to optimize the synthesis of the four-bar leverage, a new method for processing the specified conditions is proposed.

We limit ourselves to these four examples, although over the past five years, many more works have been devoted to the four-bar leverage.

A different situation is with more complex mechanisms (whose class is higher than the second, according to the AssurArtobolevsky classification). Compared to the second-class mechanisms, their use in technology is not so extensive, which is, to a certain extent, explained by a much smaller number of works devoted to their study.

These mechanisms are considered in works by E. E. Peysakh, V.A. Dzholdasbekov, V. G. Khomchenko, L. T. Dvornikov and others.

Similar works published in recent years include an article [5] in which the kinematic analysis of the fourth-class lever mechanism was taken into account when applied to a manipulator. Articles [6, 7] deal with the same issue of analysis of fourth-class mechanisms.

(C) Matsyuk I. M., Shlyahov E. M., Yehurnov O. I., 2019
Articles [8, 9] present the results of theoretical studies on the use of fourth-class lever mechanisms in crushing machines. It is demonstrated that the operation of these heavy loaded machines can cause abnormal situations associated with the proximity of two different assembly mechanisms. When designing such machines, this factor must be taken into account. The work of the friction forces in the kinematic pairs of such machines is very important, which must also be taken into account, as for example in [10]. The influence of dynamic factors is not significant and they can be ignored [11]. It is possible to move assemblies from each other by modifying the geometrical parameters of the mechanism (the length of the links), but this possibility is very limited because the geometry of the mechanism is mainly determined by the technological requirements.

Another technique is to change the position of the drive mechanism, that is to say the center of rotation of the crank and its length. To follow this path, it is necessary to formulate conditions for the existence of a crank for the mechanism of the fourth class. There is a rule known established by the German mechanic Franz Grashof at the end of the nineteenth century concerning the state of the crank for the four-bar linkage. For more complex mechanisms (third and fourth classes), these conditions are not established.

Purpose. The work is aimed at studying the influence of the location of the drive crank on the assembly modifications for the mechanism of a two-jaw crushing machine based on the fourth-class Assur group.

To achieve this goal, the following tasks were formulated:

- to determine the area of possible placement of the drive crank of the mechanism;

- to evaluate the influence of the location of the center of rotation of the crank and its length on the mounting of the mechanism;

- to evaluate the possibility of excluding close assemblies by rationally positioning the center of rotation of the crank and its length.

The solution of these problems is to be implemented using standard mathematical computer programs, as for example in $[12,13]$.

Results. We shall solve the problems formulated for the link mechanism of the fourth class which is the basis of a con- 
struction design of a crusher with compound motion of two jaws. The results of the research are given in [8].

Fig. 1 shows a circuit of this crusher.

The jaws of the crusher $C E(3)$ and $D F(4)$ move with the rotation of the crank $A B(1)$. The jaws and two three-pair links $B C D(2)$ and $E F G(5)$ form a closed four-link contour $C D F E$ in which the material 6 is crushed. The crank sets the link $\mathbf{2}$ in motion and this provides compound motion of the jaws.

The following coordinates of links $A$ and $G$ of the mechanism (m) were adopted in [8]: $x_{A}=0 ; y_{A}=0 ; x_{G}=-0.35 ; y_{G}=$ $=0.8$. Sizes of links $(\mathrm{m}): l_{A B}=0.07 ; l_{B C}=0.075 ; l_{B D}=0.15 ; l_{C E}=$ $=0.92 ; l_{D F}=0.92 ; l_{G E}=0.55 ; l_{G F}=0.2$. Angle values are taken as follows: $\alpha=36.336^{\circ} ; \beta=34^{\circ}$.

As in [8], we use the vectorial interpretation of the linkages of the lever mechanism of the crusher (Fig. 2).

To determine the possible placement area of the mechanism crank, we disconnect link $B$ and consider the 2-3-4-5 link system. We will accept the link 5 as fixed and study the possible movement of links 2-3-4 with respect to this link (Fig. 3).

To simplify, we turn the direct vector $\boldsymbol{l}_{5}$ horizontal. We have a classical four-bar linkage $E C D F$, in which either link 3 or link 4 can be a crank.

Hereinafter, all mathematical calculations are given as fragments of Mathcad program documents.

The source data of the problem are the following (vector modules in $\mathrm{m}$ ).

$$
\begin{aligned}
& \mathrm{x}_{\mathrm{G}}:=0 \quad \mathrm{y}_{\mathrm{G}}:=0 \\
& l_{2}:=0.075 \quad l_{21}:=0.15 \quad l_{3}:=0.92 \text {. } \\
& 1_{4}:=0.92 \quad 1_{5}:=0.55 \quad 1_{51}:=0.2 \\
& \alpha:=36.336 \mathrm{deg} \quad \beta:=34 \mathrm{deg}
\end{aligned}
$$

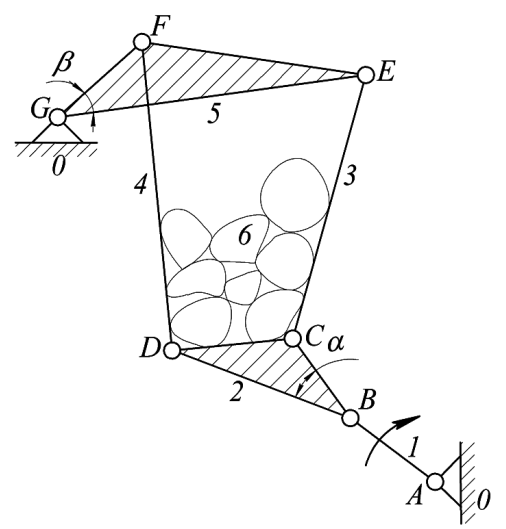

Fig. 1. Circuit of a crusher with compound motion of the laws

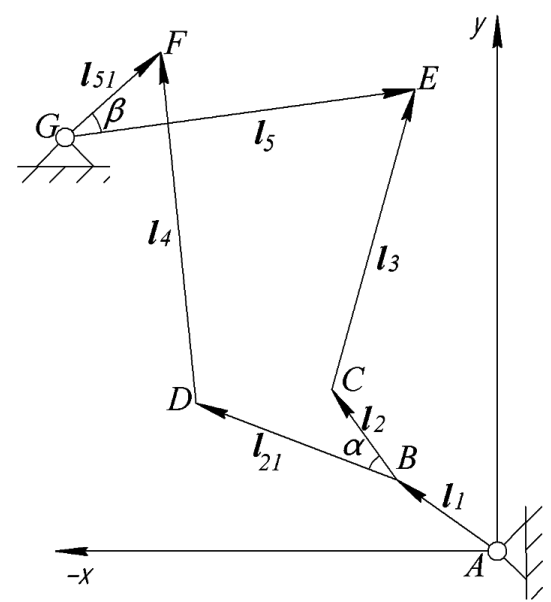

Fig. 2. Vector replacement of links of a lever mechanism of the crusher
Let us find the vector modules $\boldsymbol{l}_{22}$ and $\boldsymbol{l}_{52}$.

$$
\begin{array}{ll}
1_{22}:=\sqrt{1_{2}^{2}+1_{21}{ }^{2}-1_{2} \cdot 1_{21} \cdot 2 \cos (\alpha)} & 1_{22}=0.1 \\
1_{52}:=\sqrt{1_{5}{ }^{2}+1_{51}{ }^{2}-1_{5} \cdot 1_{51} \cdot 2 \cos (\beta)} & 1_{52}=0.4
\end{array} .
$$

It is easy to see that the Grashof rule does not apply to this mechanism (the sum of the lengths of the crank and any other link is less than the sum of the other links); therefore, the $E C D F$ mechanism is a two-rocker four-link chain.

To solve the problem, it is necessary to find the smallest and largest values of the $\boldsymbol{R}$ vector module. The area between two circles of concentric circles of radii $R_{\min }$ and $R_{\max }$ centered at point $G$ will be the area in which the drive crank should to be located. The task of finding the crank zone is, therefore, reduced to the definition of $R_{\min }$ and $R_{\max }$.

Vector closure equation for the $E C D F$ mechanism is: $\boldsymbol{l}_{22}+$ $+\boldsymbol{l}_{3}=\boldsymbol{l}_{4}+\boldsymbol{l}_{52}$.

Taking a complex form of vector representation, we get in Mathcad

$$
1_{22} \cdot \exp \left(i \cdot \phi_{22}\right)+1_{3} \cdot \exp \left(i \cdot \phi_{3}\right)=1_{4} \cdot \exp \left(i \cdot \phi_{4}\right)+1_{52} \cdot \exp \left(i \cdot \phi_{52}\right) \cdot
$$

By solving this equation for the vector $\boldsymbol{l}_{22}$ and expressing the right side by conjugate vectors, we obtain

$$
\begin{aligned}
& 1_{22}(\phi)=1_{4} \cdot \exp \left(i \cdot \phi_{4}\right)-1_{3} \cdot \exp \left(i \cdot \phi_{3}\right)+1_{52} \cdot \exp \left(i \cdot \phi_{52}\right) \\
& 1_{22}\left(\phi_{2}\right)=1_{4} \cdot \exp \left(i \cdot \phi_{4}\right)-1_{3} \cdot \exp \left(i \cdot \phi_{3}\right)+1_{52} \cdot \exp \left(i \cdot \phi_{52}\right)
\end{aligned}
$$

Let us find the angle $\varphi_{52}$ of the equation

$$
\begin{gathered}
1_{52} \cdot \exp \left(\mathrm{i} \cdot \phi_{52}\right)=1_{5}-1_{51} \cdot \exp (\mathrm{i} \cdot \beta) \\
\phi_{52}:=\frac{1}{\mathrm{i}} \cdot \ln \left(\frac{1_{5}-1_{51} \cdot \exp (\mathrm{i} \cdot \beta)}{1_{52}}\right) \quad \phi_{52}=-16.23 \mathrm{deg}
\end{gathered}
$$

By multiplying equations of the system (1) term by term and carrying out mathematical transformations, we obtain two values of the angle $\varphi_{4}$ in the angle $\varphi_{3}$ function

$$
\begin{aligned}
& \phi_{41}\left(\phi_{3}\right):=2 \operatorname{atan}\left(\frac{-\mathrm{B}\left(\phi_{3}\right)+\sqrt{\mathrm{B}\left(\phi_{3}\right)^{2}-4 \mathrm{~A}\left(\phi_{3}\right) \cdot \mathrm{C}\left(\phi_{3}\right)}}{2 \mathrm{~A}\left(\phi_{3}\right)}\right) \\
& \phi_{42}\left(\phi_{3}\right):=2 \operatorname{atan}\left(\frac{-\mathrm{B}\left(\phi_{3}\right)-\sqrt{\mathrm{B}\left(\phi_{3}\right)^{2}-4 \mathrm{~A}\left(\phi_{3}\right) \cdot \mathrm{C}\left(\phi_{3}\right)}}{2 \mathrm{~A}\left(\phi_{3}\right)}\right)
\end{aligned}
$$

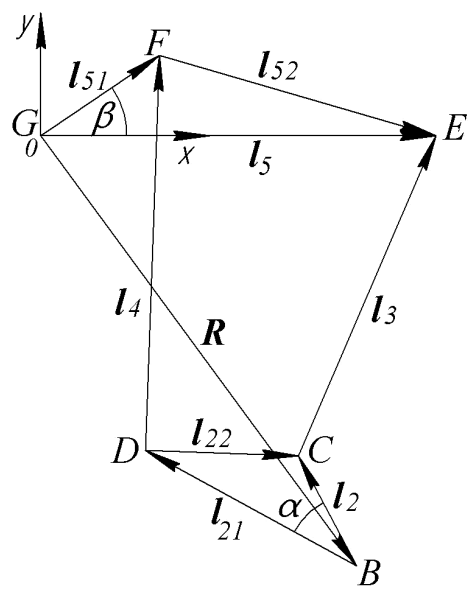

Fig. 3. To the problem of determining the extreme values of the $R$ module (distance between points $B$ and $G$ ) 
In formulas (2), $A\left(\phi_{3}\right), B\left(\phi_{3}\right)$ and $C\left(\phi_{3}\right)$ are numerical coefficients whose values depend on the angle $\phi_{3}$. In our example, for an angle of $\phi_{3}=60^{\circ}$ these coefficients are respectively 1.807; -3.344 and 1.528 .

The two values of the angle correspond to two assemblies of the four-link chain $E C D F$ (Fig. 4). To use the mechanism in the crusher, an assembly with an angle $\phi_{42}\left(\phi_{3}\right)$ is required.

To determine the vector $\boldsymbol{R}$, whose modulus characterizes the distance from point $B$ to point $G$, the value of the angles $\phi_{21}$ and $\phi_{22}$ is required.

$$
\begin{gathered}
\phi_{22}\left(\phi_{3}\right):=\arg \left(1_{4} \cdot \exp \left(\mathrm{i} \cdot \phi_{42}\left(\phi_{3}\right)\right)-\mathrm{l}_{3} \cdot \exp \left(\mathrm{i} \cdot \phi_{3}\right)+\mathrm{l}_{52} \cdot \exp \left(\mathrm{i} \cdot \phi_{52}\right)\right) \\
\phi_{21}\left(\phi_{3}\right):=\phi_{22}\left(\phi_{3}\right)-\operatorname{acos}\left(\frac{\mathrm{h}^{2}{ }^{2}+\mathrm{l}_{22}{ }^{2}-\mathrm{l}_{2}{ }^{2}}{2 \mathrm{l}_{21} \cdot \mathrm{l}_{22}}\right)+\pi
\end{gathered}
$$

We can now write the expression of the vector $\boldsymbol{R}$.

$$
\mathrm{R}\left(\phi_{3}\right):=1_{51} \cdot \exp (\mathrm{i} \cdot \beta)-1_{4} \cdot \exp \left(\mathrm{i} \cdot \phi_{42}\left(\phi_{3}\right)\right)-1_{21} \cdot \exp \left[\mathrm{i} \cdot\left(\phi_{21}\left(\phi_{3}\right)\right)\right] .
$$

To find the extreme values of the $\boldsymbol{R}$ module, we first determine the limits of variation of angle $\phi_{3}$ since the mechanism has two rockers.

The angle between vectors $\boldsymbol{l}_{3}$ and $\boldsymbol{l}_{52}$ is

$$
\phi_{352}:=\operatorname{acos}\left[\frac{1_{3}{ }^{2}+1_{52}{ }^{2}-\left(l_{4}+l_{22}\right)^{2}}{21_{3} \cdot 1_{52}}\right] \quad \phi_{352}=92.638 \mathrm{deg} .
$$

Then angle $\phi_{3}$, corresponding to the extreme right position of link 3 is

$$
\phi_{3 \mathrm{r}}:=\phi_{352}-\left|\phi_{52}\right| \quad \phi_{3 \mathrm{r}}=76.408 \mathrm{deg} .
$$

Similarly, for the left final position, we have

$$
\begin{array}{ccc}
\phi_{352}:=\operatorname{acos}\left[\frac{\left(l_{3}+1_{22}\right)^{2}+1_{52}{ }^{2}-1_{4}^{2}}{2\left(l_{3}+l_{22}\right) \cdot 1_{52}}\right] & \phi_{352}=64.29 \mathrm{deg} . \\
\phi_{31}:=\phi_{352}-\left|\phi_{52}\right| & \phi_{31}=48.06 \mathrm{deg}
\end{array}
$$

Using the built-in Mathcad special functions, we find the minimum and maximum values of the vector module $R\left(\phi_{3}\right)$.

$$
\begin{gathered}
\phi_{3}:=1 \quad \text { Given } \quad \phi_{31} \leq \phi_{3}<\phi_{3 \mathrm{r}} \\
\phi_{3 \min }:=\operatorname{Minimize}\left(\mathrm{R}, \phi_{3}\right) \\
\phi_{3 \mathrm{~min}}=48.06 \mathrm{deg}
\end{gathered}
$$
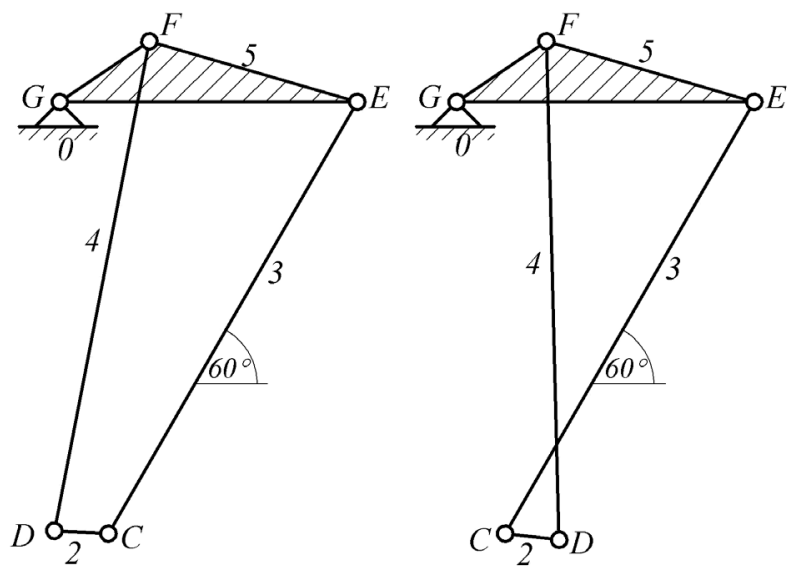

$b$

Fig. 4. Two versions of assemblies with $\varphi_{3}=60^{\circ}$ :

$a-\varphi_{4}=\varphi_{42} ; b-\varphi_{4}=\varphi_{41}$

$$
\begin{aligned}
& \mathrm{R}\left(\phi_{3 \mathrm{~min}}\right)=0.7034 \\
& \phi_{3}:=1 \quad \text { Given } \quad \phi_{31} \leq \phi_{3}<\phi_{3 \mathrm{r}} \\
& \phi_{3 \max }:=\operatorname{Maximize}\left(\mathrm{R}, \phi_{3}\right) \\
& \phi_{3 \max }=75.231 \mathrm{deg} \\
& \mathrm{R}\left(\phi_{3 \max }\right)=0.9912 \text {. }
\end{aligned}
$$

Maximum crank length is

$$
\mathrm{1}_{\mathrm{AB}}:=\frac{\mathrm{R}\left(\phi_{3 \max }\right)-\mathrm{R}\left(\phi_{3 \min }\right)}{2} \quad \mathrm{l}_{\mathrm{AB}}=0.1439 .
$$

We note that the greatest distance point $B$ from to point $G$ does not occur for the far right position of link $3\left(\phi_{3 \max }<\phi_{3 r}\right)$. If the results obtained are applied to the crusher scheme considered in [8], the following image will be obtained (Fig. 5).

For the crank to have a maximum length, it is necessary that its center of rotation is located on a circle of radius

$$
\mathrm{R}_{\mathrm{m}}:=\frac{\mathrm{R}\left(\phi_{3 \min }\right)+\mathrm{R}\left(\phi_{3 \max }\right)}{2} \quad \mathrm{R}_{\mathrm{m}}=0.8473 .
$$

We check the accuracy of the result obtained by acting in the same way as described in [8]. Let us look at the lever system of the mechanism two four-link chains $B C E G$ and $B D F G$ (Fig. 2). For each of them, at a certain position of point $B$, it is possible to construct curves of changes of angles $\phi_{5}$ and $\phi_{51}-\beta$ as a function of angle $\phi_{2}$. The presence of common points of these curves indicates that there is, on the one hand, at least one assembly of the mechanism and, on the other hand, that the number of points of intersection is the number of assemblies of the mechanism for a crank position given.

We consider the length of the crank to be slightly less than the maximum length and equal to $l_{A B}=0.14 \mathrm{~m}$, as well as the coordinates of the center of its rotation $x_{A}=0 \mathrm{~m}$ and $y_{A}=0 \mathrm{~m}$ (point $A$ is on a circle of radius $R_{m}=0.8473 \mathrm{~m}$ ). Then the coordinates of point $G$ are: $x_{G}=-0.1846 \mathrm{~m}$ and $y_{G}=0.8269 \mathrm{~m}$.

We will turn the crank according to the law

$$
\phi_{1}:=\frac{\pi}{4} \cdot(\mathrm{n}-1),
$$

where $n$ takes integer values between 1 and 8 , which corresponds to the complete rotation of the crank. We are convinced that in each of these positions the mechanism has two assemblies, with the nearest assemblies being at $n=7$ that is when $\phi_{1}=270^{\circ}$ (Fig. 6).

In this fragment, we took angle $\phi_{1}$ change step to be equal $45^{\circ}$ and, with a value of $\phi_{1}=270^{\circ}$, we got the closest assemblies. It is possible that in the vicinity of this value, there are even closer assemblies, which can easily be verified by decreasing the angle $\phi_{1}$ change step accordingly.

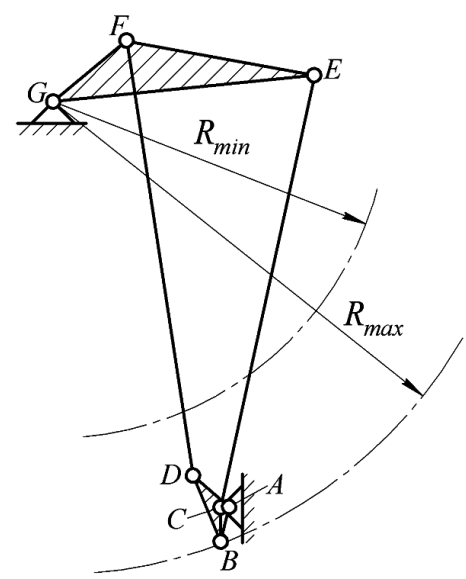

Fig. 5. The zone of the possible positioning of the crank with a compound motion of the jaws 


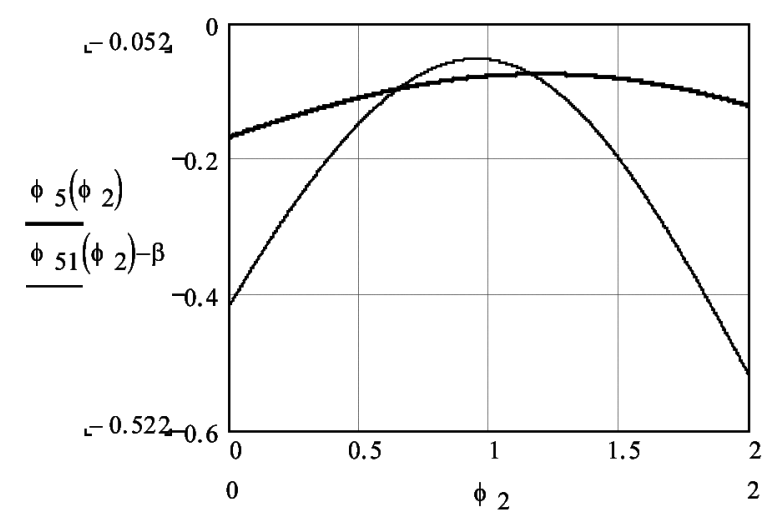

Fig. 6. Closely spaced assemblies of the mechanism, differing in the values of the angle $\phi_{2}\left(36.96^{\circ}\right.$ and $\left.66.31^{\circ}\right)$

Let us transfer the center of rotation of the crank to the left along the same arc and take $x_{G}=-0.13 \mathrm{~m}$ and $y_{G}=0.8269 \mathrm{~m}$. The closest assemblies also appear at $\phi_{1}=270^{\circ}$ and are characterized by the values of the angle $\phi_{2}\left(35.27^{\circ}\right.$ and $\left.61.55^{\circ}\right)$. We shift point $A$ to the right, putting $x_{G}=-0.24$ and $y_{G}=0.8126$. And in this case, the closest assemblies also occur at $\phi_{1}=270^{\circ}$ and are characterized by the values of the angle $\phi_{2}\left(38.27^{\circ}\right.$ and $\left.71.65^{\circ}\right)$. On the basis of the actions performed, it can be concluded that, at the maximum length of the crank, the displacement of the center of its rotation along the arc of the middle circle for the area of the radius found has no tangible effect on the arrangement of two different assemblies of the mechanism.

We estimate the effect of crank length on the positioning of two different assemblies of the mechanism. For the first variant of the position of the center of rotation of the crank and for $l_{A B}=0.1 \mathrm{~m}$ with $\phi_{1}=270^{\circ}$, we have two assemblies with the values of the angle $\phi_{2}\left(1.35^{\circ}\right.$ and $\left.103.24^{\circ}\right)$. There is no danger in this neighborhood.

Thus, reducing the length of the crank has a positive effect by "pushing" close assemblies of the mechanism.

Conclusions. As a result of the research, it was found that:

- for planar lever mechanisms containing a fourth-class structural group, the drive crank zone can be found using the algorithm presented in this article;

- at the maximum length of the crank, the displacement of its center of rotation slightly affects the arrangement of the mechanism assemblies;

- reduction of the length of the crank significantly affects the mutual arrangement of the mechanism assemblies and, by modifying this parameter, it is possible to eliminate the dangerous proximity of two assemblies, which plays an important role in heavy loaded mechanisms.

\section{References.}

1. Todorov, T. S. (2015). Synthesis of Four Bar Mechanisms as Functon Generators by Freudenstein-Chebyshev. Journal of Robotics and Mechanical Engineering Research, 1(1). DOI: 10.24218/jrmer.2015.01.

2. Jaiswal, A., \& Jawale, H. P. (2018). Synthesis and optimization of four bar mechanism with six design parameters. In $M a$ terial Science and Engineering with Advanced Research Journal. Proceedings of the First International Conference on Design, Materials and Manufacture, 1943(1). DOI: 10.1063/1.5029590. 3. Cvetković, I., Stojičevic, M., Popkonstantinović, B., \& Cvetković, D. (2018). Classification, geometrical and kinematic analysis of four-bar linkages sinteza. In International scientific conference on information technology and data related research (pp. 261-266). DOI: 10.15308/Sinteza-2018261-266.

4. Sleesongsom, S., \& Bureerat, S. (2018). Optimal Synthesis of Four-Bar Linkage Path Generation through Evolutionary Computation with a Novel Constraint Handling Technique.
Computational Intelligence and Neuroscience, 2018. DOI: 10.1155/2018/5462563.

5. Tultayev, B., Balbayev, Gm., \& Zhauyt, A. (2017). A Kinematic Analysis of Flat Leverage Mechanism of the Fourth Class for Manipulators. In IOP Conference Series: Materials Science and Engineering, 230. DOI: 10.1088/1757-899X/230/ $1 / 012047$.

6. Koshel, S., \& Koshel, G. (2016). Analysis of planar mechanisms of higher classes with movable closed loop circuit. Herald Of Khmelnytskyi National University. Technical sciences, 4, 15-19.

7. Koshel, S., \& Koshel, G. (2018). Analysis of fourth class plane mechanisms with structural groups of links of the second order. Odes'kyi Politechnichnyi Universytet. Pratsi, 1(54), 12-17.

8. Matsyuk, I. N., Shlyahov, E. M., \& Yehurnov, O. I. (2018). Some aspects of synthesis of linkage of complex structures. Naukovyi Visnyk Natsionalnoho Hirnychoho Universytetu, 3, 57-63. DOI: 10.29202/nvngu/2018-3/14.

9. Matsyuk, I. N., Shlyahov, E. M., \& Yehurnov, O. I. (2019). On applying high-class mechanisms of heavy-loaded machines. Naukovyi Visnyk Natsionalnoho Hirnychoho Universytetu, 3, 68-73. DOI: 10.29202/nvngu/2019-3/6.

10. Ziborov, K., \& Fedoriachenko, S. (2014). The frictional work in pair wheel-rail in case of different structural scheme of mining rolling stock. Progressive Technologies of Coal, Coalbed Methane, and Ores Mining (pp. 517-521). DOI: 10.1201/b17547. 11. Iljin, S., Samusya, V., Iljina, I., \& Iljina, S. (2015). Influence of dynamic processes in mine winding plants on operating safety of shafts with broken geometry. New Developments in Mining Engineering 2015: Theoretical and Practical Solutions of Mineral Resources Mining, 425-429.

12. Belmas, I., \& Kolosov, D. (2011). The stress-strain state of the stepped rubber-rope cable in bobbin of winding. Technical and Geoinformation Systems in Mining: School of Underground Mining, 2011, 211-214. Retrieved from https://www.researchgate.net/publication $/ 330310760$ The stress strain state of the stepped rubber rope cable in bobbin of winding 13. Kolosov, D., Dolgov, O., \& Kolosov, A. (2014). Analytical determination of stress-strain state of rope caused by the transmission of the drive drum traction. Progressive Technologies of Coal, Coalbed Methane, and Ores Mining, 499-504.

\section{Обгрунтування раціональних параметрів приводу для надійної роботи важконавантажених механізмів}

\section{I. М. Мацюк ${ }^{1}$, Е. М. Шляхов ${ }^{1}$, О. I. Егурнов ${ }^{2}$}

1 - Національний технічний університет „Дніпровська політехніка“, м. Дніпро, Україна, e-mail: shlyahove@nmu. org.ua

2-ВАТ „Ана-Темс“, м. Дніпро, Україна, e-mail: yegurnov@ yahoo.com

Мета. Оцінити вплив параметрів приводного кривошипу на розташування різних складань механізму зі структурною групою четвертого класу.

Методика. У роботі виконане теоретичне дослідження впливу параметрів вхідного кривошипу на розташування різних складань механізму двощокової дробарки з використанням програмного продукту Mathcad.

Результати. Показано, що:

- центр обертання й довжина кривошипу в механізмі четвертого класу повинні розташовуватися в певній зоні;

- вибором конкретного місця розташування кривошипу можна виключити небезпечну близькість двох сусідніх складань механізму.

Наукова новизна. Для плоских механізмів зі структурною групою четвертого класу встановлено алгоритм ви- 
значення зони розташування центру обертання кривошипу та його довжини. Встановлено також, що ймовірність спонтанного переходу з одного складання на інше близько розташованих складань у важконавантажених механізмах може бути суттєво зменшена вибором відповідного розташування центру обертання кривошипу.

Практична значимість. Запропоновано алгоритм дій, що дозволяє при синтезі плоского важконавантаженого механізму четвертого класу вибирати складання, яке забезпечує його безаварійну роботу.

Ключові слова: механізм, синтез, структурна група, складання, кривошип, щокова дробарка, програма Mathcad

\section{Обоснование рациональных параметров привода для надежной работы тяжелонагруженных механизмов}

\author{
И. Н. Мацюк ${ }^{1}$, Э. М. Шляхов ${ }^{1}$, А. И. Егурнов ${ }^{2}$
}

1 - Национальный технический университет „Днепровская политехника“, г. Днепр, Украина, e-mail: shlyahove@ nmu.org.ua

2 - ООО „Ана-Темс“, г. Днепр, Украина, e-mail: yegurnov@yahoo.com

Цель. Оценить влияние параметров приводного кривошипа на расположение различных сборок механизма со структурной группой четвертого класса.
Методика. В работе выполнено теоретическое исследование влияния параметров входного кривошипа на расположение различных сборок механизма двухщековой дробильной машины с использованием программного продукта Mathcad.

Результаты. Показано, что:

- центр вращения и длина кривошипа в механизме четвертого класса должны располагаться в определенной зоне;

- выбором конкретного места расположения кривошипа можно исключить опасную близость двух соседних сборок механизма.

Научная новизна. Для плоских механизмов со структурной группой четвертого класса установлен алгоритм определения зоны расположения центра вращения кривошипа и его длины. Установлено также, что вероятность спонтанного перехода с одной сборки на другую близкорасположенную сборку в тяжелонагруженных механизмах может быть существенно уменьшена выбором соответствующего расположения центра вращения кривошипа.

Практическая значимость. Предложен алгоритм действий, позволяющий при синтезе плоского тяжелонагруженного механизма четвертого класса выбирать сборку, обеспечивающую его безаварийную работу.

Ключевые слова: механизм, синтез, структурная групnа, сборки, кривошип, щековая дробилка, программа Mathcad

Рекомендовано до публікації докт. техн. наук B. А. Ропаєм. Дата надходження рукопису 24.01.19. 